\title{
The Influence of Intellectual Capital, Firm Size, and Firm Growth on Firm Value with Profitability as Moderating Variable on Companies That are Joined in the Jakarta Islamic Index And Listed on the Indonesia Stock Exchange 2016-2019 Period
}

\author{
Aji Sugandi', Rina Br Bukit ${ }^{1}$, Tarmizi ${ }^{1}$ \\ ${ }^{1}$ Department of Accounting, Faculty of Economics and Business at Universitas Sumatera Utara, Indonesia
}

Corresponding Author: Aji Sugandi

\begin{abstract}
The purpose of this study was to determine and examine the effect of intellectual capital, firm size, and firm growth on firm value in companies that are incorporated in the Jakarta Islamic Index and listed on the Indonesia Stock Exchange and test whether profitability can moderate the relationship between the independent variables and the dependent variable. This research is causal research using secondary data. The population of this study is companies that are members of the Jakarta Islamic Index listed on the Indonesia Stock Exchange from 2016 to 2019. The method of determining the sample uses a saturated sample so that a sample of 57 companies is obtained multiplied by four years of research to obtain 228 observations. The analysis technique used in this study uses panel data regression analysis and moderating test with Eviews 10 software tools.

The results of this study partially intellectual capital have a negative and significant effect on firm value. Firm size has a negative and significant effect on firm value, and firm growth has a positive and significant effect on firm value. The profitability variable moderates the relationship between the influence of intellectual capital and firm size on firm value and does not moderate the relationship between the effect of firm growth on firm value.
\end{abstract}

Keywords: Intellectual Capital, Firm size, Firm growth, Profitability, Firm Value.

\section{INTRODUCTION}

In industrial revolution 4.0, where science and technology are increasingly sophisticated, business competition is increasingly competitive. Of course, the company must prepare a strategy to compete with other companies to attract investors to invest in the company by increasing its value. Firm value gives investors a perception of the company's level of success, which is associated with stock prices. High stock prices certainly make the company value high, thereby increasing investor confidence in the company's prospects in the future (Khairat, 2017).

To increase the company's value, managers must pay attention to the factors that can influence it. Some of them are intellectual capital, firm size, firm growth, and profitability, which theoretically affect company value. According to stakeholder theory, the company must provide benefits to all stakeholders and not only for its benefit itself. In this theory, managers must increase and create value from the activities carried out and minimized losses for their stakeholders. This theory assumes that organizational accountability is not only limited to profitability, dividend policy, and liquidity, but it is also necessary to disclose intellectual capital because it affects the value of the company itself (Khairat, 2017). 
Aji Sugandi et.al. The influence of intellectual capital, firm size, and firm growth on firm value with profitability as moderating variable on companies that are joined in the Jakarta Islamic index and listed on the Indonesia stock exchange 2016-2019 period.

The following is a picture of the average rise and fall of the Price to Book Value (PBV) ratio that reflects the company value and Return On Assets (ROA) in companies that are members of the Jakarta Islamic Index (JII) in 2016-2019, namely:

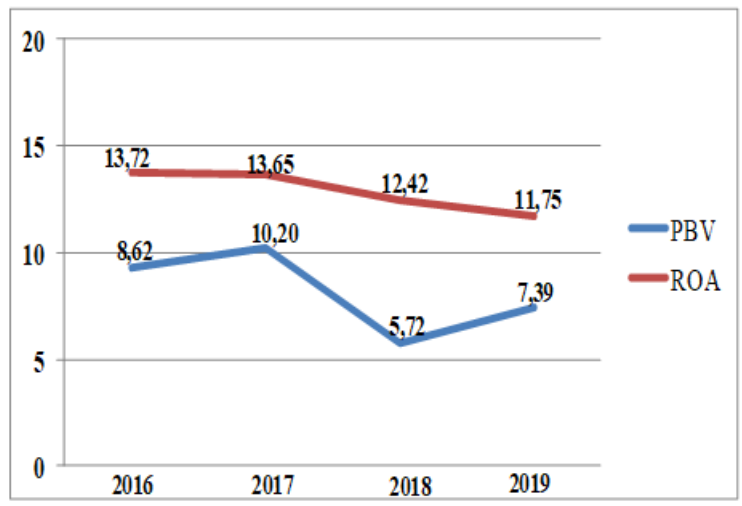

Figure 1. Graph of the average PBV and ROA of JII companies in 2016-2019

Source: $w w w . I D X . c o . i d$

In Figure 1. it can be seen that in 2016 the average PBV ratio, which was initially 8.62 increased to 10.20 , and there was a significant decline in 2018 to 5.72 and increased again in 2019 to 7.39. Several factors can cause fluctuations in the company's value, and one of the factors is the company's profitability. The company's profitability shows whether the company has good prospects or not in the future. Of course, it is something that the company must pay attention to create profitability and added value for the company so that investors are interested in investing (Sayyidah \& Saiffi, 2017).

Profitability is a ratio of management effectiveness that can be seen from the return on sales and investment, which is the ability of a company to generate profits from its operational results and its equity (Dessyana, 2016). According to signaling theory, when profitability increases, the value of the company will also increase. Vice versa, when profitability decreases, the value of the company will also decrease (Khairat, 2017). However, this is not in line with Figure 1. In 2019, when profitability fell to 11.75 , the company's value rose to 7.39 . Hence, there is a theoretical gap that makes researchers interested in testing it again in this study. Profitability is proxied using Return On Assets (ROA). The reason researchers use ROA because ROA interprets the results of a series of company policies (strategies) and reflects management's ability to manage all resources to generate profits (Simarmata, 2015).

Industrial revolution 4.0 impacts changes in the workforce used by companies, namely from human power to mechanical power. Although human labor is still used in the company, the company will reduce the number of employees in terms of quantity. Reducing the number of employees will certainly benefit the company in terms of operational cost-efficiency regarding employee costs. However, when the company replaces human labor with mechanical power, it will impact the company, especially in reducing the value of intellectual capital owned by the company. Intellectual capital is an intangible asset that includes intellectual property rights, patents, copyrights, and franchises that can increase value for the company (Sirapanji \& Hatane, 2015). Brennan (2001) explains that intellectual capital is the knowledge that can increase the value of high assets to increase the company's value.

In this study, intellectual capital is proxied using the Value Added Intellectual Coefficient $\left(\mathrm{VAIC}^{\mathrm{TM}}\right.$ ). Researchers chose VAIC $^{\mathrm{TM}}$ because $\mathrm{VAIC}^{\mathrm{TM}}$ is an analytical procedure designed to enable management, shareholders, and other relevant stakeholders to actively monitor and evaluate the efficiency of adding value to the company's resources. The main components of $\mathrm{VAIC}^{\mathrm{TM}}$ developed by Pulic (1998) consist of Value Added Capital Employed (VACA), Value Added Human Capital (VAHU), and Structural Capital Value Added (STVA).

VACA is the added value created from physical capital, which compares Value Added (VA) and Capital Employed (CA). Capital Employed describes the harmonious relationship between the 
Aji Sugandi et.al. The influence of intellectual capital, firm size, and firm growth on firm value with profitability as moderating variable on companies that are joined in the Jakarta Islamic index and listed on the Indonesia stock exchange 2016-2019 period.

company and its partners (Belkaoui, 2003). VAHU is the added value generated from the workforce for the company for the funds spent to finance the workforce. Pramudita (2012) explains that the more value-added is produced, the more efficient the company can manage human resources to produce a quality workforce and impact the company's financial performance. STVA shows the contribution of Structural Capital (SC) informing value-added. In the Pulic model, $\mathrm{SC}$ is VA minus HC. This ratio is used to measure how many SCs are needed to generate each rupiah of added value (Jayati, 2016).

The results of Nuryaman's research (2013) show that intellectual capital affects firm value. The results of this study are in line with Sirapanji \& Hatane (2015). In contrast to Khairat (2017) and Sayyidah \& Saifi (2017) results, which obtained the results that intellectual capital does not affect firm value.

Firm size describes the size of a company, which is indicated by the company's total assets and total sales. Companies that have large total assets show that the company has reached the maturity stage so that it is seen as having promising prospects in the eyes of investors. In addition, considerable company assets will make the company more stable and exercise better control over market conditions to face economic competition (Lumoly, Murni, \& Untu, 2018). Information about the company's value in the market is essential because it can signal investors about the company's state that can increase investor confidence to invest in the company to increase its value (Putra \& Lestari, 2016). In this study, the company's size is proxied using Firm Size, which is seen from the company's total assets.

The results of Bandanuji and Khoiruddin's (2020) research show that firm size has a positive effect on firm value. The results of this study are in line with Dharma \& Rasyid (2020), Rizqia et al. (2013), and Lumapow \& Tumiwa (2017). In contrast to the research results by Islam et al. (2017), which obtained the results, firm size did not affect firm value.

Firm growth is the level of development of a company that can be seen from its total assets. In this case, the growth of the company is proxied using growth. Growth shows asset growth, where assets are assets used by the company in carrying out its operations (Sari \& Suryantini, 2019). From the investor's point of view, firm growth is a sign that the company has good corporate performance so that the expected rate of return on investment is high (Maryam et al., 2020). In general, companies that overgrow get positive results in strengthening their position in the era of competition, enjoying significantly increased sales and accompanied by an increase in market share. It can increase investor confidence, which impacts increasing firm value (Nikmatussolichan et al., 2018). The increasing growth of the company will undoubtedly affect its value of the company. When the company's growth is high, the company's value will also increase (Syaiulhaq et al., 2020).

The research results by Fajaria \& Isnalita (2018) show that the company's growth affects the company's value. This result is supported by the research of Liestyasih \& Wiagustini (2017). In contrast to the research results of Kartika (2020) and Oktaviani (2020), which obtained the results that firm growth did not affect firm value.

This research was conducted on companies that are members of the Jakarta Islamic Index (JII) and listed on the Indonesia Stock Exchange (IDX) from 2016 to 2019. Researchers are interested in researching companies incorporated in Islamic stocks due to the interest of Islamic capital market investors every year continues to experience significant growth. CNBC Indonesia data shows that the number of Islamic capital market investors continues to experience significant growth. The Indonesia Stock Exchange recorded that until March 2019, the number of Islamic capital market investors reached 
Aji Sugandi et.al. The influence of intellectual capital, firm size, and firm growth on firm value with profitability as moderating variable on companies that are joined in the Jakarta Islamic index and listed on the Indonesia stock exchange 2016-2019 period.

50,500 investors, increasing from 2018 to 44,536 (CNBC Indonesia, 2019).

Based on the phenomenon of fluctuations in the PBV ratio in companies that are members of JII in 2016 - 2019, the results of previous research are inconsistent, as well as the high interest of investors in Islamic stocks. The researchers are interested in researching with the title "The Influence of Intellectual Capital on Firm Value With Profitability as a Variable Moderating on Companies That Are Joined in the Jakarta Islamic Index and Listed on the Indonesia Stock Exchange for the 20162019 Period".

\section{Framework}

Following the description of the background of the problem, literature review, and previous research, a conceptual research framework is prepared as follows:

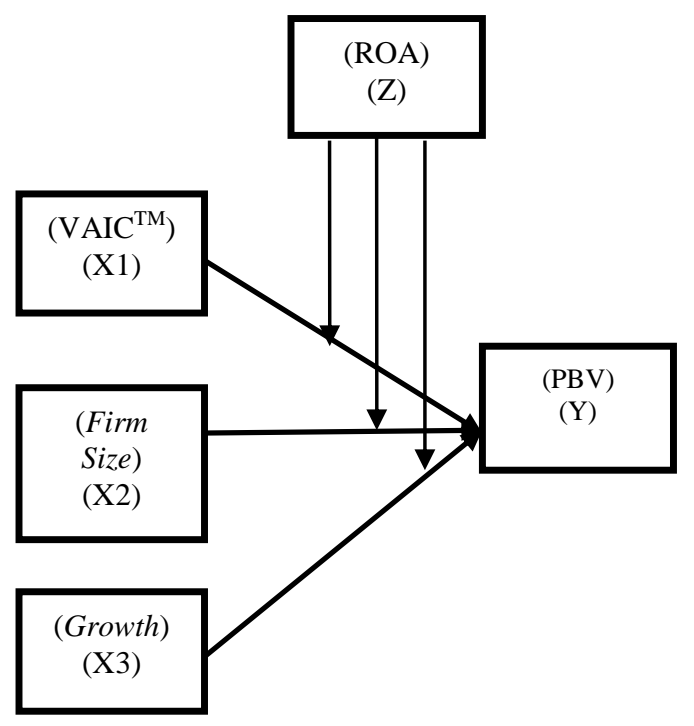

Figure 2. Conceptual Framework

H1: Intellectual Capital has a positive effect on Firm Value

$\mathrm{H} 2$ : Firm size has a positive effect on firm value

H3: Firm growth has a positive effect on Firm Value

H4: Profitability moderates the positive influence relationship between Intellectual Capital on Firm Value
H5: Profitability moderates the positive influence relationship between Firm Size and Firm Value

H6: Profitability moderates the positive influence relationship between Firm Growth and Firm Value

\section{RESEARCH METHODS}

This type of research is causal associative research to determine the effect of Intellectual Capital, Firm Size, and Firm Growth as independent variables on Firm Value as the dependent variable with Profitability as the moderating variable. The causal associative study analyzes the relationship between one variable and another to know how one variable affects other variables (Erlina, 2011). The data analysis method used in this study is a statistical analysis method using Eviews10 software. Data analysis performs by testing standard assumptions and testing hypotheses.

The population used in this study is 57 companies that are members of the JII listed on the IDX in 2016-2019. The sampling technique in this study was using a saturated sampling technique.

\section{RESULT AND DISCUSSION Normality Test}

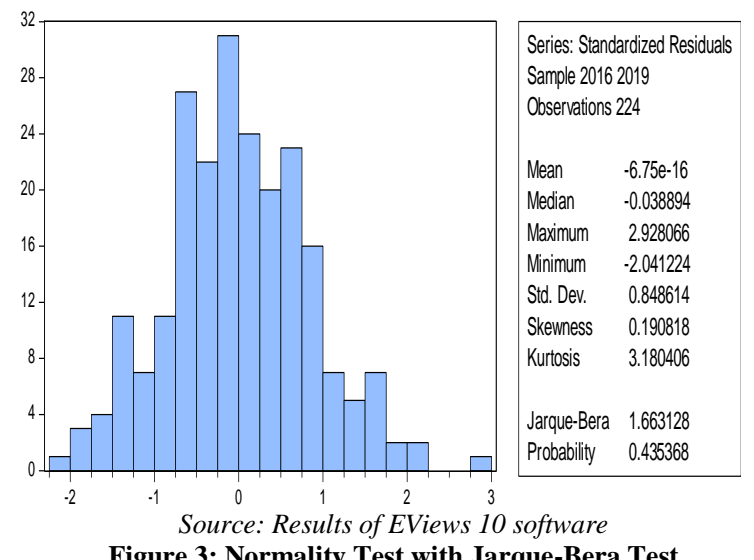

Based on the table above, it can be concluded that the probability value of 0.435368 is greater than 0.05 , so that the data is normally distributed. So that further testing can be carried out. 
Aji Sugandi et.al. The influence of intellectual capital, firm size, and firm growth on firm value with profitability as moderating variable on companies that are joined in the Jakarta Islamic index and listed on the Indonesia stock exchange 2016-2019 period.

Panel Data Regression Model Estimation

To analyze panel data, what must be done is to analyze the Common Effect Model (CEM), Fixed Effect Model (FEM), and Random Effect Model (REM) to determine the appropriate model to use.

\section{Common Effect Model Test}

Table 1. Common Effect Model Test Results

\begin{tabular}{|l|l|l|l|l|}
\hline Variable & Coefficient & Std. Error & t-Statistic & Prob. \\
\hline C & 2.565372 & 0.308492 & 8.315853 & 0.0000 \\
\hline Log_X1 & -1.002003 & 0.076402 & -13.11491 & 0.0000 \\
\hline Log_X2 & -0.080897 & 0.074582 & -1.084675 & 0.2792 \\
\hline Log_X3 & 0.129451 & 0.198777 & 0.651234 & 0.5156 \\
\hline \multicolumn{5}{|c|}{ Source: Results of EViews 10 software } \\
\hline
\end{tabular}

\section{Fixed Effect Model (FEM) Test}

Table 2. Test of Fixed Effect Model

\begin{tabular}{|l|l|l|l|l|}
\hline Variable & Coefficient & Std. Error & t-Statistic & Prob. \\
\hline C & -4.891543 & 2.082121 & -2.349308 & 0.0200 \\
\hline Log_X1 & -0.472278 & 0.145502 & -3.245841 & 0.0014 \\
\hline Log_X2 & -0.672047 & 0.258617 & -2.598618 & 0.0102 \\
\hline Log_X3 & 6.245691 & 1.475447 & 4.233083 & 0.0000 \\
\hline \multicolumn{5}{|c|}{ Source: Results of EViews 10 software } \\
\hline
\end{tabular}

\section{Random Effect Model Test}

Table 3. Random Effect Model Test

\begin{tabular}{|l|l|l|l|l|}
\hline Variable & Coefficient & Std. Error & t-Statistic & Prob. \\
\hline C & 2.825675 & 0.811729 & 3.481056 & 0.0006 \\
\hline Log_X1 & -0.805393 & 0.239423 & -3.363892 & 0.0009 \\
\hline Log_X2 & -0.091717 & 0.160604 & -0.571074 & 0.5685 \\
\hline Log_X3 & -0.022788 & 0.550857 & -0.041368 & 0.9670 \\
\hline \multicolumn{5}{|c|}{ Source: Results of EViews 10 software } \\
\hline
\end{tabular}

\section{Panel Data Regression Model Selection Chow test}

\begin{tabular}{|c|c|c|c|}
\hline \multicolumn{4}{|c|}{ Table 4. Chow test } \\
\hline Effects Test & Statistic & d.f. & Prob. \\
\hline Cross-section F & 4.951310 & $(56,168)$ & 0.0000 \\
\hline
\end{tabular}

The table above shows that the probability value of 0.0000 is smaller than 0.05, so the Fix Effect Model (FEM) is better than the Common Effect Model (CEM).

\section{Hausman test}

\begin{tabular}{|} 
Table 5. Hausman Test \\
\begin{tabular}{|l|l|l|l|}
\hline Test Summary & $\begin{array}{l}\text { Chi-Sq. } \\
\text { Statistic }\end{array}$ & $\begin{array}{l}\text { Chi-Sq. } \\
\text { d.f. }\end{array}$ & Prob. \\
\hline Cross-section random & 9.960385 & 3 & 0.0189 \\
\hline
\end{tabular} \\
\hline
\end{tabular}

The table above shows that the probability value $=0.0189$ is smaller than
0.05 , so the model that is feasible to use is the Fixed Effect Model (FEM).

The Langrange Multiplier (LM) test aims to see between the CEM or REM models. This test is needed when the Chow test result is CEM, and the Hausman test result is REM. In this study, the results of the Chow test were FEM, so there was no need for the LM test.

\section{Hypothesis test Coefficient of Determination Test}

Table 6. Coefficient of Determination Test
\begin{tabular}{|l|l|}
\hline R-Squared & 0.763543 \\
\hline Adjusted R-Squared & 0,680502 \\
\hline S.E. of regression & 0.707019 \\
\hline F-Statistic & 9.194737 \\
\hline Prob(F-Statistic) & 0,000000 \\
\hline \multicolumn{2}{|c|}{ Source: Results of EViews 10 software }
\end{tabular}

Based on the table above, it can be seen that the value of Adjusted R Square is 0.680502, which indicates that the magnitude of the role or contribution of the independent variable, namely intellectual capital, firm size, and firm growth, which can explain the dependent variable, namely company value is $68.1 \%$. In comparison, other variables explain the remaining $31,9 \%$.

\section{T-test (Partial Test)}

\begin{tabular}{l} 
Table 7. T-test \\
\begin{tabular}{|l|l|l|l|l|}
\hline Variable & Coefficient & Std. Error & t-Statistic & Prob. \\
\hline C & -4.891543 & 2.082121 & -2.349308 & 0.0200 \\
\hline Log_X1 & -0.472278 & 0.145502 & -3.245841 & 0.0014 \\
\hline Log_X2 & -0.672047 & 0.258617 & -2.598618 & 0.0102 \\
\hline Log_X3 & 6.245691 & 1.475447 & 4.233083 & 0.0000 \\
\hline
\end{tabular} \\
\hline
\end{tabular}

\section{Moderated Regression Analysis (MRA)}

\begin{tabular}{l} 
Table 8. Moderating Test \\
\begin{tabular}{|l|l|l|l|l|}
\hline Variable & Coefficient & Std. Error & t-Statistic & Prob. \\
\hline C & 4.048088 & 2.064713 & 1.960606 & 0.0516 \\
\hline Log_X1 & -0.074161 & 0.198895 & -0.372865 & 0.7097 \\
\hline Log_X2 & -0.589405 & 0.232413 & -2.536024 & 0.0121 \\
\hline Log_X3 & -1.729327 & 1.535885 & -1.125948 & 0.2618 \\
\hline Log_X1*Z & 1.156493 & 0.065328 & 17.70292 & 0.0000 \\
\hline Log_X2*Z & 0.610359 & 0.107587 & 5.673158 & 0.0000 \\
\hline Log_X3*Z & -3.11E-08 & $8.78 \mathrm{E}-08$ & -0.353994 & 0.7238 \\
\hline
\end{tabular} \\
\hline
\end{tabular}

\section{CONCLUSION}

Based on the results of data analysis and research discussion, the following conclusions can be drawn: 
Aji Sugandi et.al. The influence of intellectual capital, firm size, and firm growth on firm value with profitability as moderating variable on companies that are joined in the Jakarta Islamic index and listed on the Indonesia stock exchange 2016-2019 period.

1. Intellectual Capital as proxied using $\mathrm{VAIC}^{\mathrm{TM}}$ partially has a negative and significant effect on company value as proxied using PBV.

2. Firm size as proxied using Firm Size partially has a negative and significant effect on firm value proxied using PBV.

3. The company's growth proxied using growth partially has a positive and significant effect on the company's value proxied using PBV.

4. Profitability proxied using Return On Assets (ROA) moderates the positive relationship between the influence of Intellectual Capital as proxied using $\mathrm{VAIC}^{\mathrm{TM}}$ on firm value as proxied using PBV.

5. Profitability proxied using Return On Assets (ROA) moderates the positive relationship between the effect of Firm Size proxied using Firm Size on firm value proxied using PBV.

6. Profitability, as proxied using Return On Assets (ROA), does not moderate the relationship between the effect of firm growth as proxied using growth on firm value proxied using PBV.

\section{RESEARCH LIMITATIONS}

1. Companies that are members of the Jakarta Islamic Index are different (Heterogeneous).

2. The intellectual capital variable used using VAIC $^{\mathrm{TM}}$ is a combination of 3 components of intellectual capital so that each component can still be tested into individual variables.

\section{SUGGESTION}

Based on the conclusions and limitations that have been found, the researcher provides several suggestions, including:

1. Future researchers should use companies with the same type of business (heterogeneous).

2. Further researchers are advised to make each component of intellectual capital into a variable to determine what components can affect the dependent variable.

\section{Acknowledgement: None}

\section{Conflict of Interest: None}

\section{Source of Funding: None}

\section{REFERENCES}

1. Bandanuji, A., \& Khoiruddin, M. (2020). The Effect of Business Risk and Firm Size on Firm Value with Debt Policy as Intervening Variable. Management Analysis Journal.

2. Belkaoui, A.R. 2003. "Intellectual Capital and Firm Performance of US.

3. Brennan, Niamh. 2001. "Reporting Intellectual Capital in Annual Reports

4. CNCB Indonesia (2019). Investor Pasar Modal Syariah Meningkat Tahun 2019,https://www.cnbcindonesia.com/sy ariah/20190506171551-29-70802/maret2019-investor-pasar-modal-syariah50500-orang, Di akses Tanggal 24 September 2019.

5. Dessyana (2016). Faktor-Faktor Yang Mempengaruhi Nilai Perusahaan Pada Perusahaan Manuaktur Yang Terdatar di Bursa Efek Indonesia dengan Profitabilitas Sebagai Variabel Intervening. Tesis. Universitas Sumatera Utara

6. Dharma, D. A., \& Rasyid, R. (2020). Faktor-Faktor Yang Mempengaruhi Nilai Perusahaan Pada Perusahaan Manufaktur. Jurnal Multiparadigma Akuntansi Tarumanegara .

7. Erlina. 2011. Metodologi Penelitian. Medan: USU Press.,

8. Fajaria, A. Z., \& Isnalita. (2018). The Effect of Profitability, Liquidity, Leverage and Firm Growth of Firm Value with its Dividend Policy as a Moderating Variable. International Journal of Managerial Studies and Research (IJMSR).

9. Islam, N., SU, A., \& M, A. (2017). Impact of Working Capital Management on Profitability: A Study on Textile 
Aji Sugandi et.al. The influence of intellectual capital, firm size, and firm growth on firm value with profitability as moderating variable on companies that are joined in the Jakarta Islamic index and listed on the Indonesia stock exchange 2016-2019 period.

Companies of Bangladesh. Journal of Business \& Financial Affairs

10. Jayati, E.S. (2016). Pengaruh Intellectual Capital Terhadap Kinerja Keuangan Perusahaan Perdagangan Jasa Yang Terdaftar di Bursa Efek Indonesia. Skripsi. Universitas Negeri Yogyakarta. Journal, Vol. 5, No. 2, pp 171-180.

11. Kartika, R. (2020). Analysis Of Size, ROA, and Growth of Corporate Value; With Variabel Capital Structure As Intervening. International journal of science, engineering, and information technology.

12. Khairat, A. (2017). Pengaruh Intellectual Capital Dan Intellectual Disclosure Terhadap Kinerja Keuangan Dan Nilai Perusahaan Dalam Indeks LQ45 Yang Terdaftar Di BEI Pada Priode 2012-2015.Universitas Negeri Medan.

13. Liestyasih, L. P., \& Wiagustini, L. P. (2017). Pengaruh Firm Sie dan Growth Opportunity Terhadap Cash Holding dan Firm Value. E-Jurnal Ekonomi dan Bisnis Universitas Udayana .

14. Lumapow, L. S., \& Tumiwa, R. A. (2017). The Effect of Dividend Policy, Firm Size, and Productivity on The Firm Value. Research Journal of Finance and Accounting.

15. Lumoly, S., Murni, S., \& Untu, V. N. (2018). Pengaruh Likuiditas, Ukuran Perusahaan dan Profitabilitas Terhadap Nilai Perusahaan Studi Pada Perusahaan Logam dan Sejenisnya yang Terdaftar di Bursa Efek Indonesia . Jurna EMBA , 1108-1117.

16. Maryam, S., Mus, A. R., \& Priliyadi, A. (2020). Pengaruh Ukuran Perusahaan, Pertumbuhan Perusahaan, Likuiditas, Profitabilitas, dan Kebijakan Dividen Terhadap Nilai Perusahaan. Center of Economic Student Journal.

17. Nikmatussolichan, Mahsuni, A. W., \& Afifudin. (2018). Pengaruh Profitabilitas, Likuiditas, dan Pertumbuhan Perusahaan Terhadap Kebijakan Dividen dan Nilai Perusahaan Pada Perusahaan Manufaktur Yang
Terdaftar di BEI Tahun 2015-2017. EJRA .

18. Nuryaman. (2015). The Influence Of Intellectual Capital On The Firm's Value With The Financial Performance As Intervening Variable. Science Direct, 292-298.

19. Oktaviani, R. F. (2020). Effect of Firm Growth and Firm Sie on Company Value With Earning Per Share as Moderation. Economic and Accounting Journal.

20. Pramudita, G. (2012). Pengaruh Intellectual Capital Terhadap Nilai Pasar dan Kinerja Keuangan Perusahaan Perbankan Yang Terdaftar di BEI Tahun 2008-2010.Universitas Diponegoro.

21. Pulic, A. 1998. Measuring The Performance of Intellectual Potential in Knowledge Economy. www.vaic-on.net. Diakses tanggal 10 Desember 2019.

22. Putra, A. N., \& Lestari, P. V. (2016). Pengaruh Kebijakan Dividen, Likuiditas, Profitabilitas dan Ukuran Perusahaan Terhadap Nilai Perusahaan. E-Jurnal Manajemen Unud , 4044-4070.

23. Rizqia, D. A., Aisjah, S., \& Sumiati. (2013). Effect of Managerial Ownership, Financial Leverage, Profitability, Firm Size, and Investment Opportunity on Dividend Policy and Firm Value. Research Journal of Finance and Accounting.

24. Sari, N. P., \& Suryantini, N. P. (2019). Pengaruh Profitabilitas, Likuiditas, dan Tingkat Pertumbuhan Terhadap Kebijakan Dividen Pada Perusahaan Manufaktur. E-Jurnal Manajemen , 4559-4588.

25. Sayyidah, U., \& Saifi, M. (2017). Pengaruh Intellectual Capital Terhadap Nilai Perusahaan Dengan Profitabilitas Sebagai Variabel Moderasi (Studi Pada Perusahaan Pada Perusahaan Sub Sektor Property dan Real Estate Di Bursa Efek Indonesia Periode 2013-2015). Jurnal Administrasi Bisnis (JAB). Vol. 46, No. 1.

26. Simarmata, Rhoma. 2015. Pengaruh Intellectual Capital Terhadap Kinerja 
Aji Sugandi et.al. The influence of intellectual capital, firm size, and firm growth on firm value with profitability as moderating variable on companies that are joined in the Jakarta Islamic index and listed on the Indonesia stock exchange 2016-2019 period.

Keuangan Dan Nilai Perusahaan

Perbankan Yang Terdaftar Di Bursa

Efek Indonesia. Universitas Negeri Semarang.

27. Sirapanji, O., \& Hatane, S. E. (2015).

Pengaruh Value Added Intellectual Capital Terhadap Kinerja Keuangan Dan Nilai Pasar Perusahaan Khususnya Di Industri Perdagangan Jasa Yang Terdatar Di Bursa Eek Indonesia Tahun 2008-2013. Business Accounting Review Vol 3, No. 1, 45-54.

28. Syaiulhaq, M. D., Herwany, A., \& Layyinaturrobaniyah. (2020). Capital Structure and Firm's Growth in
Relations to Firm Value at Oil and Gas Companies Listed in Indonesia Stock Exchange. Journal of Accounting Auditing and Business

How to cite this article: Sugandi A, Rina $\mathrm{Br}$ Bukit, Tarmizi. The influence of intellectual capital, firm size, and firm growth on firm value with profitability as moderating variable on companies that are joined in the Jakarta Islamic index and listed on the Indonesia stock exchange 2016-2019 period. International Journal of Research and Review. 2021; 8(7): 296-303. DOI: https://doi.org/10.52403/ijrr.20210741 